\section{Evaluation of Drought Tolerance and Avoidance Traits for Six Creeping Bentgrass Cultivars}

\author{
Stephen E. McCann and Bingru Huang ${ }^{1}$ \\ Department of Plant Biology, Cook College, Rutgers University, Room 301 \\ Foran Hall, 59 Dudley Road, New Brunswick, NJ 08901-8520 \\ Additional index words. Agrostis stolonifera, turfgrass, drought stress
}

\begin{abstract}
The objectives of this study were: 1) to compare drought responses between the more recently developed creeping bentgrass cultivars to standard cultivars and 2) to determine differential drought tolerance and avoidance characteristics associated with cultivar variation in drought resistance. Six cultivars of creeping bentgrass (Agrostis stoloniferia) ('Penn A-4', 'Independence', 'Declaration', 'L-93', 'Penncross', and 'Putter') were maintained in growth chambers at $20^{\circ} \mathrm{C}$ day $/ 15^{\circ} \mathrm{C}$ night either well-watered or exposed to drought stress by withholding water for 17 days. Cultivars varied in turf performance and physiological responses (leaf relative water content and photochemical efficiency) to drought stress, which was reflected in their differences in drought tolerance (osmotic adjustment) and drought avoidance traits (water use rate and efficiency, root viability, root length, and number). 'Penn A-4,' 'Independence,' and 'L-93' generally performed better than other three cultivars under drought conditions, mainly through maintaining higher water use efficiency, root viability, root elongation, or root production. The majority of physiological parameters evaluated suggested that of the six creeping bentgrass cultivars examined in this study, the three cultivars with better ability to survive drought stress used mainly avoidance traits related to water use and water uptake.
\end{abstract}

In response to drought stress, plants develop various adaptive mechanisms, including drought tolerance and avoidance strategies (Nilsen and Orcutt, 1996). Plants may avoid drought stress by maintaining favorable water status under drought either by increasing the capacity for water uptake of roots or reducing water loss from leaves. Previous studies with turfgrass species have shown that extensive root systems and root viability contribute positively to water uptake and thus, plant survival of drought through avoiding water deficit (Bonos and Murphy, 1999; Huang et al., 1997; Jiang and Huang, 2001; Sheffer et al., 1987). Some plant species are able to tolerate low water content in plant tissues, exhibiting growth and maintenance of metabolic processes even under cellular water deficit. Drought tolerance may be accomplished through various mechanisms such as osmotic adjustment (OA), which involves accumulation of solutes to maintain cellular turgidity. Drought tolerance has been positively correlated with $\mathrm{OA}$ in many species, including turfgrasses (DaCosta and Huang, 2006; Qian and Fry, 1997; White et al., 1992).

Interspecific variation in drought survival strategies have been demonstrated in previous studies. Some turfgrass species such

Received for publication 25 Sept. 2007. Accepted for publication 14 Nov. 2007.

We thank Dr. Michelle DaCosta and Emily Merewitz for critical reviewing the manuscript.

${ }^{1}$ To whom reprint requests should be addressed; e-mail huang@aesop.rutgers.edu as buffalograss [Buchloe dactyloides (Nutt.) Engelm.], seashore paspalum (Paspalum vaginatum Swartz), and tall fescue (Festuca arundinacea Schreb.) have been found to exhibit drought avoidance characteristics associated with enhanced root extension deeper in the soil profile for greater extraction of water (Carrow, 1996; Ervin and Koski, 1998; Huang, 1999; Huang et al., 1997). Drought tolerance traits such as osmotic adjustment have been exhibited in grass species like creeping bentgrass (Agrostis stolonifera L.) (DaCosta and Huang, 2006), Kentucky bluegrass (Poa pratensis L.) (Perdomo et al., 1996), and zoysiagrass (Zoysia japonica Steud.) (Qian and Fry, 1997). Regardless, adaptation of specific plant species to periods of drought stress is not limited to the use of a single mechanism, but can use both avoidance and tolerance traits as a means to survival (Nilsen and Orcutt, 1996). Any specific mechanism may be influenced by a variety of factors, including both the amount and length that water is withheld as well as specific genetic variation in both species and cultivar. Although differential drought resistance strategies have been studied extensively among species, limited research has been conducted to examine cultivar variation in drought tolerance and avoidance characteristics. Genetic differences among cultivars in drought tolerance or avoidance traits could be exploited by turf breeders as selection criterion in breeding programs working toward improved drought resistance.

Creeping bentgrass is a widely used coolseason turfgrass species on golf courses. Breeding efforts in recent years have led to the development of creeping bentgrass cultivars with improved turfgrass quality characteristics and greater biotic and abiotic stress tolerance (Bonos et al., 2004; Engelke et al., 1995). Newer cultivars such as 'Declaration', 'Independence', 'Penn A-4', and 'L-93' have been used widely on golf courses. However, little is known of the improvement in drought performance of these newer cultivars relative to older standard cultivars such as 'Penncross' and the mechanisms they use in the adaptation to drought stress. The objectives of this study were: 1) to compare drought tolerance among the more recently developed creeping bentgrass cultivars with other standard cultivars and 2) to determine differential drought tolerance and avoidance characteristics associated with cultivar variation in drought resistance.

\section{Materials and Methods}

Plant materials. Sod pieces of six cultivars of creeping bentgrass (Agrostis stoloniferia L.) ('Penn A-4', 'Declaration', 'Independence', 'L-93', 'Penncross', and 'Putter') were transplanted from field plots into polyvinyl chloride tubes $(10 \mathrm{~cm}$ diameter and $40 \mathrm{~cm}$ length) filled with sterilized sandy loam soil (50\% fine-loamy, mixed mesic Typic Hapludult; $50 \%$ sand). Plants were maintained in a greenhouse under 10 to $12 \mathrm{~h}$ natural light conditions and temperatures of $\approx 21{ }^{\circ} \mathrm{C}$ day $/ 13{ }^{\circ} \mathrm{C}$ night for 3 months in the winter of 2006 to 2007 and then moved to a walk-in growth chamber where treatments were imposed. The growth chamber was maintained at $20^{\circ} \mathrm{C}$ day $/ 15^{\circ} \mathrm{C}$ night, $70 \%$ humidity, $12-\mathrm{h}$ photoperiod, and photosynthetically active radiation of $450 \mu \mathrm{mol} \cdot \mathrm{m}^{-2} \cdot \mathrm{s}^{-1}$ at canopy height. Plants tubes were watered three times per week to maintain soil moisture at field capacity. Tubes were watered until collection containers underneath each tube had water fill into them, giving us the reasonable assumption that field capacity was reached. Plants were fertilized weekly with $100 \mathrm{~mL}$ of a soluble $20-20-20\left(\mathrm{~N}-\mathrm{P}_{2} \mathrm{O}_{5}\right.$ $\mathrm{K}_{2} \mathrm{O}$ ) fertilizer (Peter's General Purpose 20 20-20; Grace-Sierra Horticultural Products Company, Milpitas, CA; including micronutrients: $\mathrm{Mg} 0.05 \%$, B 0.0068, Cu 0.0036, Fe 0.05, Mn 0.025, Mo 0.0009, Zn 0.0025) at a concentration of $5 \mathrm{~g} \cdot \mathrm{L}^{-1}$ before exposure to drought. Actual $\mathrm{N}$ applied at $123.35 \mathrm{~kg} \cdot \mathrm{ha}^{-1}$. Grasses were cut every $2 \mathrm{~d}$ with scissors, with clippings removed, and maintained at $\approx 4-\mathrm{cm}$ height.

Treatments and experimental design. The six cultivars were exposed to two soil water treatments: 1) well-watered control: plants were watered every other day to soil reaching field capacity; and 2) drought stress: irrigation was withheld for $17 \mathrm{~d}$. Each treatment was replicated four times in space (different containers). The cultivars and treatments were arranged as a randomized complete block design in the growth chamber (a total of 48 containers). Repeated measurements were made on four replicates for each treatment. Statistical significance of data was tested 
using the analysis of variance procedure (SAS Institute, Cary, NC). Differences between treatment means were separated by Fisher's protected least significance difference test at the $0.05 P$ level.

Measurements. Water use characteristics were evaluated by measuring soil volumetric water content (VWC), leaf relative water content (RWC), evapotranspiration (ET), and osmotic potential $\left(\psi_{\mathrm{S}}\right)$ when plants were well watered $\left(\psi_{\pi 100}\right)$. Measurements were taken on a weekly basis. Soil volumetric water content in 0 - to 20 -cm soil depth (where most roots are located in turfgrass) was measured with the time domain reflectometry method (Soil Moisture Equipment, Santa Barbara, CA) using a $20-\mathrm{cm}$ long probe inserted in the top $20 \mathrm{~cm}$ soil. Relative water content was calculated using the formula: $100 *[(\mathrm{FW}-$ $\mathrm{DW}) /(\mathrm{TW}-\mathrm{DW})]$, where FW is leaf fresh weight, TW is leaf turgid weight, and DW is leaf dry weight after oven-drying leaf samples for $72 \mathrm{~h}$ at $100{ }^{\circ} \mathrm{C}$. Turgid weight was determined as weight of fully turgid leaves after soaking leaves in distilled water in the refrigerator for $24 \mathrm{~h}$. Evapotranspiration rate was determined by the gravimetric mass balance method. Pots were weighed every $24 \mathrm{~h}$ to calculate the total water lost through comparison of differences in weight between the two measurements.

Osmotic adjustment $\left(\psi_{\pi 100}\right)$ was determined according to the rehydration method, in which $\psi_{\pi 100}$ of leaves was determined after soaking in water for full rehydration (Blum, 1989; Blum and Sullivan, 1986). Turgid leaf samples were frozen in liquid nitrogen and subsequently stored at $-20^{\circ} \mathrm{C}$ until analysis of leaf $\psi_{\mathrm{s}}$. Frozen tissue samples were thawed and cell sap was pressed from leaves, which was subsequently analyzed for osmolality $(\mathrm{C})\left(\mathrm{mmol} \cdot \mathrm{kg}^{-1}\right)$ using a vapor pressure

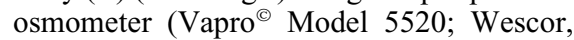
Logan, UT). Osmolality of cell sap was converted from $\mathrm{mmol} \cdot \mathrm{kg}^{-1}$ to $\psi_{\mathrm{S}}(\mathrm{MPa})$ using the formula: $\mathrm{MPa}=-\mathrm{C} \times 2.58 \times 10^{-3}$. Osmotic adjustment was determined as the difference in $\psi_{\mathrm{S}}$ between well-watered and droughtexposed plants.

Plant tissue was sampled for carbon isotope analysis at $14 \mathrm{~d}$ of treatment. Leaf tissue was dried at $80^{\circ} \mathrm{C}$ and ground to a powder to pass through a 40 -mesh screen. Carbon isotope composition $\left(\delta^{13} \mathrm{C}\right)$ was analyzed by Augustana College, Biology Department, Sioux City, SD. A more detailed description on carbon isotope analysis and theory were reported in Smedley et al. (1991) and Ebdon et al. (1998).

Turf quality was visually rated on a scale of 1 to 9 with a rating of 1 being a completely desiccated brown turf canopy and a rating of 9 representing healthy plants with dark green, turgid leaf blades, and a dense turf canopy (Turgeon, 1999). A rating of 6 was considered the minimal acceptable turf quality level.

Leaf photochemical efficiency was estimated by measuring the variable to maximum fluorescence ratio $\left(\mathrm{F}_{\mathrm{v}} / \mathrm{F}_{\mathrm{m}}\right)$ in the nonenergized state accomplished by exposure to darkness. Measurements were made of intact leaves with a chlorophyll fluorescence meter (ADC BioScientific, Hoddesdon, UK) after plants were adapted to darkness for $30 \mathrm{~min}$.

After the treatment period, all roots in each container were washed free of soil. Root viability was determined using a representative sample from each container and measuring dehydrogenase activity with the triphenyltetrazolium chloride (TTC) reduction technique (Knievel, 1973; McMichael and Burke, 1994). A different representative sample from each container was digitally imaged using WinRhizo 2002 computer software (Regent Instruments, Quebec, Canada). Total root length and total number of roots were determined using the WinRhizo 2002 program.

\section{Results}

Turf quality and leaf photochemical efficiency. Turf quality was maintained at $\approx 8.0$ throughout the treatment period in all cultivars with no cultivar variations under well-watered conditions (Fig. 1). Under drought stress, turf quality exhibited a steady decline, and the rate of decline varied between cultivars. All cultivars exposed to drought maintained acceptable turf quality (6.0 or higher) within $7 \mathrm{~d}$ of drought stress. By 14 d of drought, only 'Penn A-4', 'L-93', and 'Penncross' maintained acceptable quality, and 'Penn A-4' had significantly higher turf quality (7.0) than all other cultivars except 'L-93' (6.5); 'L-93' had significantly higher turf quality than 'Declaration' (5.75), 'Independence' (5.75), and 'Putter' (5.25). By $17 \mathrm{~d}$ of drought stress, turf quality of all cultivars declined to below the acceptable turf quality level; 'Penn A-4' and 'Independence' had significantly higher turf quality than 'Declaration', 'Penncross', and 'Putter' but did not differ from 'L-93'.

Well-watered plants maintained constant leaf photochemical efficiency $\left(\mathrm{F}_{\mathrm{v}} / \mathrm{F}_{\mathrm{m}}\right)$ throughout the duration of the study with no significant differences between cultivars on any days of treatment (Fig. 2). In droughtstressed plants, $\mathrm{F}_{\mathrm{v}} / \mathrm{F}_{\mathrm{m}}$ was maintained at the well-watered control level during $7 \mathrm{~d}$ of treatment but declined to below their respective control level by $14 \mathrm{~d}$ of treatment in all cultivars, with the exception of 'Penn A-4', in which $F_{\mathrm{v}} / \mathrm{F}_{\mathrm{m}}$ was not different from the control. At 7 and $14 \mathrm{~d}$ of drought, 'Penn A-4' had a significantly higher $F_{v} / F_{m}$ than all other cultivars. 'Independence' and 'L-93' had a significantly higher $\mathrm{F}_{\mathrm{v}} / \mathrm{F}_{\mathrm{m}}$ than 'Putter' at $14 \mathrm{~d}$ of drought stress. At $17 \mathrm{~d}$ of drought, no significant differences in $F_{v} / F_{m}$ were observed between cultivars.

Plant water relations. Soil VWC of pots was $\approx 20 \%$ at study initiation with no differences between treatments (data not shown). At the study's conclusion $(17 \mathrm{~d})$, soil volumetric in well-watered plants remained $\approx 20 \%$, whereas all drought-exposed plants had VWC below 5\%.

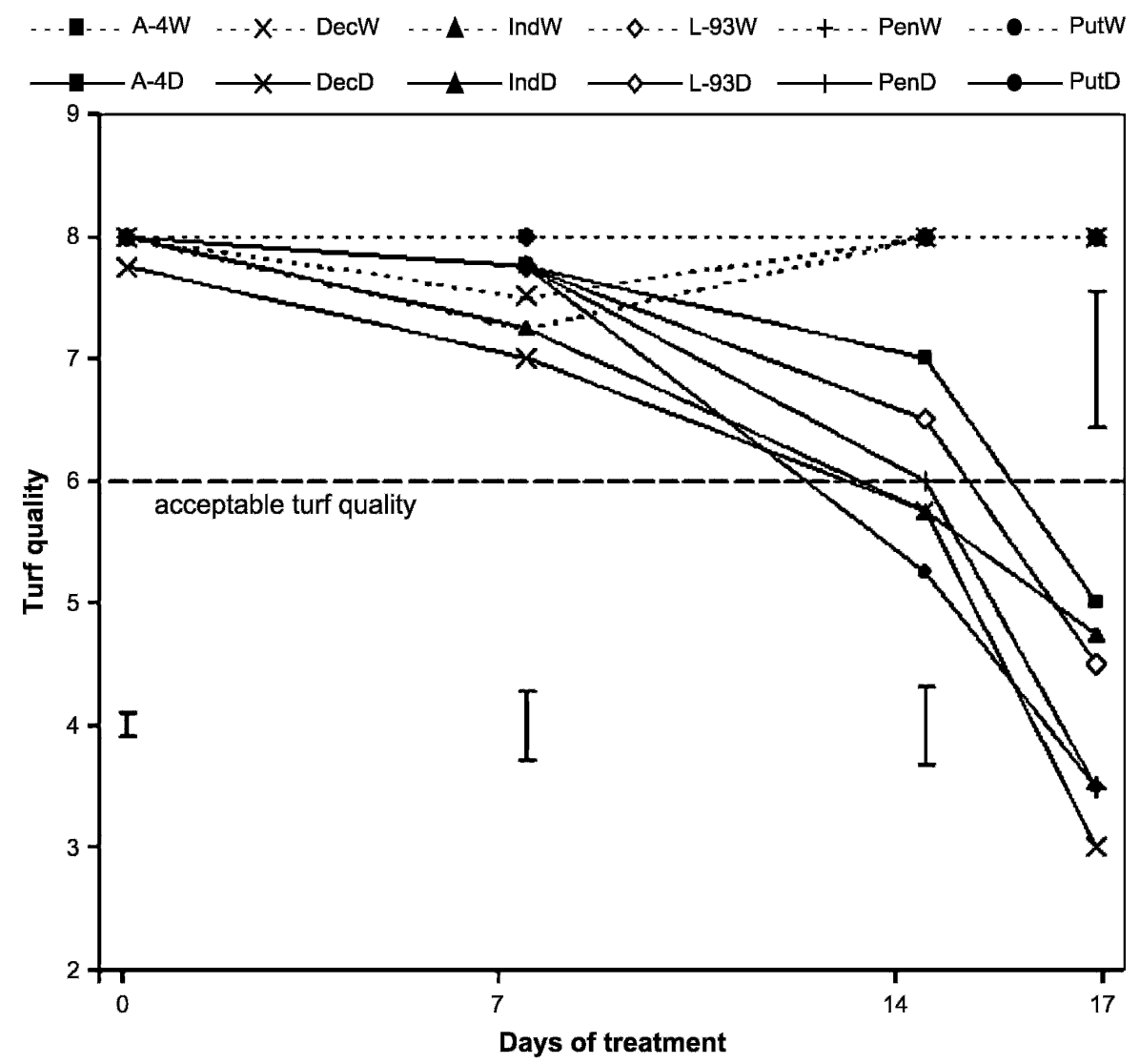

Fig. 1. Creeping bentgrass cultivar variation in turf quality under well-watered (dotted line) and drought stress (solid line). Vertical bars indicate least significant difference values $(P=0.05)$ for cultivar and treatment comparisons at a given day of treatment. 
Leaf RWC of well-watered plants averaged $\approx 90 \%$ throughout the treatment period with no significant differences among cultivars (Fig. 3). Under drought stress, significant declines in RWC were observed by $14 \mathrm{~d}$, dropping to below $50 \%$ in all cultivars. At $14 \mathrm{~d}$ of drought stress, 'Penn A-4' and 'Independence' had significantly higher RWC than 'Penncross' and 'Putter'. At $17 \mathrm{~d}$ of drought stress, 'Independence' had significantly higher RWC than 'Declaration', 'Penncross', and 'Putter'.

Significant differences in OA were detected among six cultivars exposed to drought stress for $14 \mathrm{~d}$ (Fig. 4). OA of 'Penn A-4' and 'L93' was significantly lower than 'Declaration' and 'Penncross'. No significant differences in OA were detected among 'Declaration', 'Independence', 'Penncross', and 'Putter'.

Evapotranspiration rates of well-watered plants varied among cultivars (Fig. 5). 'L-93' generally had the lowest ET rate among the six cultivars, lower than 'Penncross' at 5 to $7 \mathrm{~d}$, 'Penn A-4' at 10 to $11 \mathrm{~d}$, and 'Declaration' at 10 to $11 \mathrm{~d}, 12$ to $14 \mathrm{~d}$, and 16 to $18 \mathrm{~d}$. Significant declines in ET rates of droughtstressed plants were observed by 10 to $11 \mathrm{~d}$ in all cultivars. At 12 to $14 \mathrm{~d}$ of drought stress, 'Penn A-4' maintained significantly greater ET than 'Putter'. No cultivar difference in ET was observed on other treatment days.

Carbon isotope discrimination ratio $\left(\delta^{13} \mathrm{C}\right)$ was lowest in 'Penncross', highest in 'Declaration', and intermediate in the other four cultivars under well-watered conditions (Fig. 6). $\delta^{13} \mathrm{C}$ of plants exposed to drought stress significantly increased in all cultivars, with the exception of 'Penn A-4', compared with well-watered plants. Cultivars also varied in $\delta^{13} \mathrm{C}$ under drought stress, which ranked as: 'Penn A-4' < 'Penncross' = 'L-93' $\leq$ 'Independence' = 'Putter' = 'Declaration'.

Root characteristics. Root viability, expressed as TTC reduction, did not vary significantly among cultivars under wellwatered conditions (data not shown). However, root viability did vary among cultivars exposed to drought stress (Fig. 7). 'Independence' maintained significantly higher root viability in the upper 20 -cm soil layer compared with 'Penn A-4', 'Declaration', 'L-93', and 'Penncross' and in the lower $20 \mathrm{~cm}$ soil than all five other cultivars. No difference in root viability was detected among 'Penn A-4', 'Declaration', 'L-93', 'Putter', and 'Penncross' at either soil depth.

Total root length varied among cultivars under well-watered conditions, with 'Declaration', 'Penncross', and 'Putter' having longest root systems and 'L-93' had the shortest root system. Total root length of droughtstressed plants decreased significantly for 'Declaration' and 'Putter', which was $46 \%$ and $40 \%$ lower than the well-watered control plants, respectively (Fig. 8). 'Penn A-4', 'Independence', and 'L-93' showed no significant decline in total root length under drought stress compared with their respective wellwatered control.

No cultivar variation in the number of roots was observed under well-watered con-

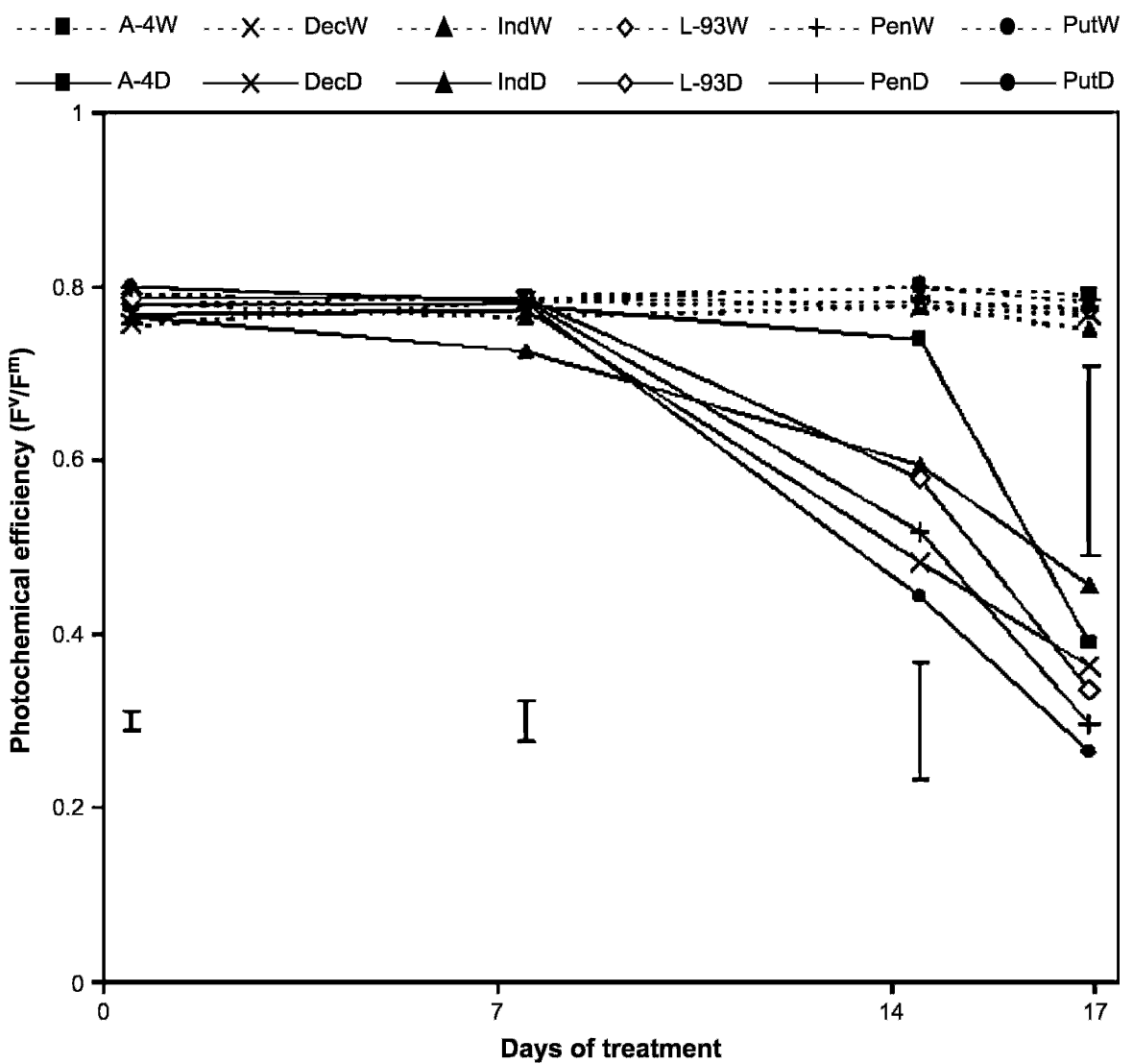

Fig. 2. Creeping bentgrass cultivar variation in leaf photochemical efficiency $\left(\mathrm{F}_{\mathrm{v}} / \mathrm{F}_{\mathrm{m}}\right)$ under well-watered (dotted lines) and drought stress (solid lines). Vertical bars indicate least significant difference values $(P=0.05)$ for cultivars and treatment comparisons at a given day of treatment.

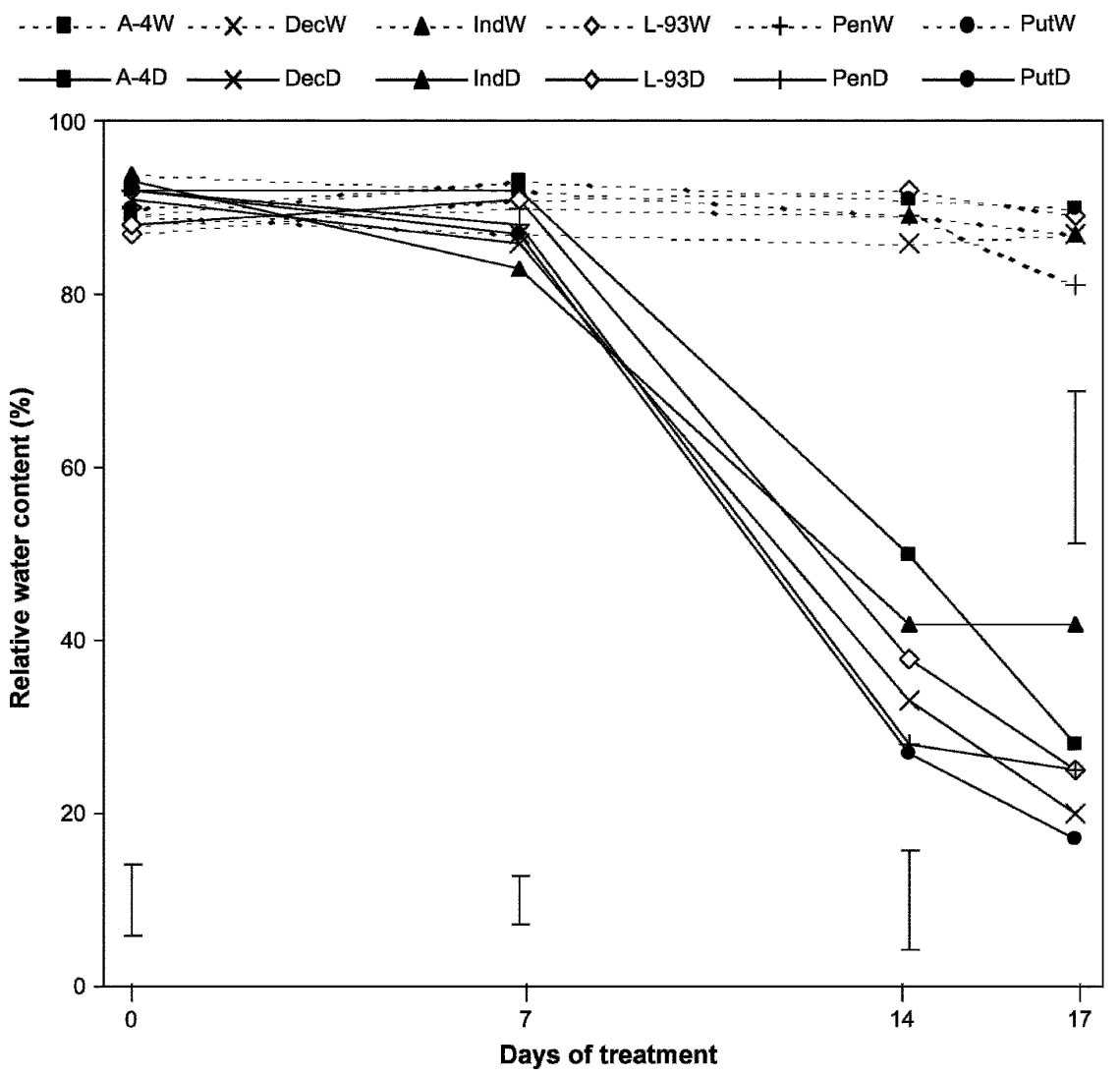

Fig. 3. Creeping bentgrass cultivar variation in leaf relative water content under well-watered (dotted lines) and drought stress (solid lines). Vertical bars indicate least significant difference values $(P=0.05)$ for cultivar and treatment comparisons at a given day of treatment. 


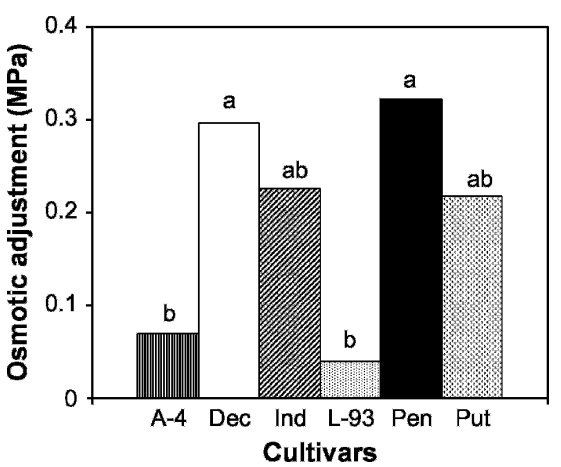

Fig. 4. Creeping bentgrass cultivar variation in osmotic adjustment under drought stress. Columns with the same lowercase letters are not significantly different based on least significant difference values $(P=0.05)$.

ditions (Fig. 9). Under drought stress, 'Penn A-4' had the most number of roots, which was significantly higher than 'Declaration' but not different from other cultivars. 'Declaration' exhibited significant decline in the number of roots under drought stress, whlrease other cultivars maintained the number of roots at their respective control level (Fig. 9).

\section{Discussion}

Quality ratings and leaf photochemical efficiency results demonstrated that 'Penn A-4', 'Independence', and 'L-93' were generally better able to maintain growth and metabolic activity under drought stress than the other three cultivars evaluated in the current study. The better drought resistance of the three newer bentgrass cultivars could be primarily attributed to drought avoidance traits such as reduced water use and improved rooting characteristics as discussed in details in the following section.

Leaf RWC is a widely used parameter to determine the level of internal water status. During a prolonged period of drought (14 d), drought-exposed 'Penn A-4', 'Independence', and 'L-93' had higher RWC than the other cultivars, with 'Penn A-4' and 'Independence' being significantly higher than 'Penncross' and 'Putter'. The maintenance of leaf water status is essential for continuation of physiological and biochemical functioning. Plants that can maintain adequate RWC for a longer period of time under drought exposure will have the greatest likelihood of continued metabolic functioning and survival. In the current study, higher RWC was associated positively with higher turf quality $\left(\mathrm{R}^{2}=0.8238\right)$ and leaf photochemical efficiency $\left(\mathrm{R}^{2}=0.7945\right)$, with 'Penn A-4' and 'Independence' rating highest in both parameters. This suggested that cultivars with greater drought resistance were able to maintain higher cellular hydration under drought conditions.

Osmotic adjustment has been identified as a drought tolerance mechanism in many species (Bohnert et al., 1995; LaRosa et al., 1987). Increasing OA facilitates the maintenance of cell turgor under conditions of limited water availability. In the present
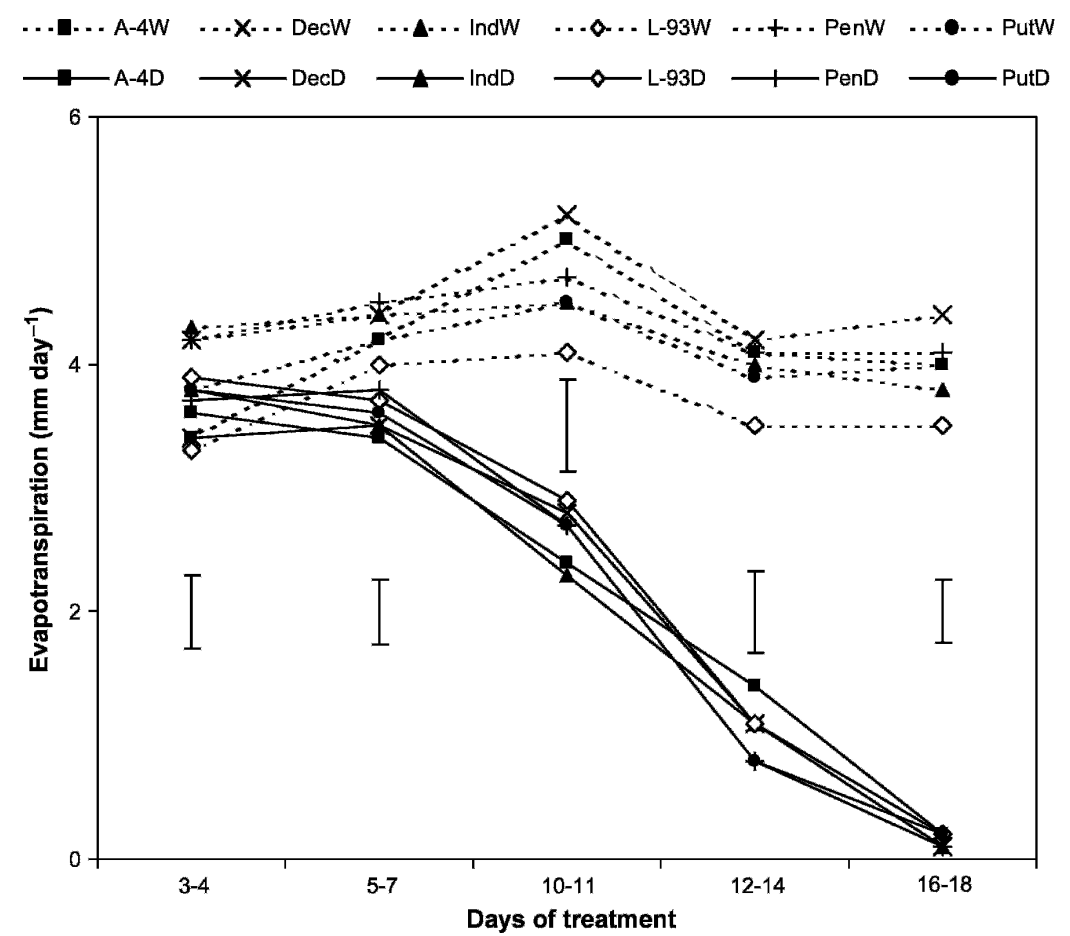

Fig. 5. Creeping bentgrass cultivar variation in evapotranspiration rate under well-watered (dotted lines) and drought stress (solid lines) Vertical bars indicate least significant difference values $(P=0.05)$ for cultivar and treatment comparisons at a given day of treatment.

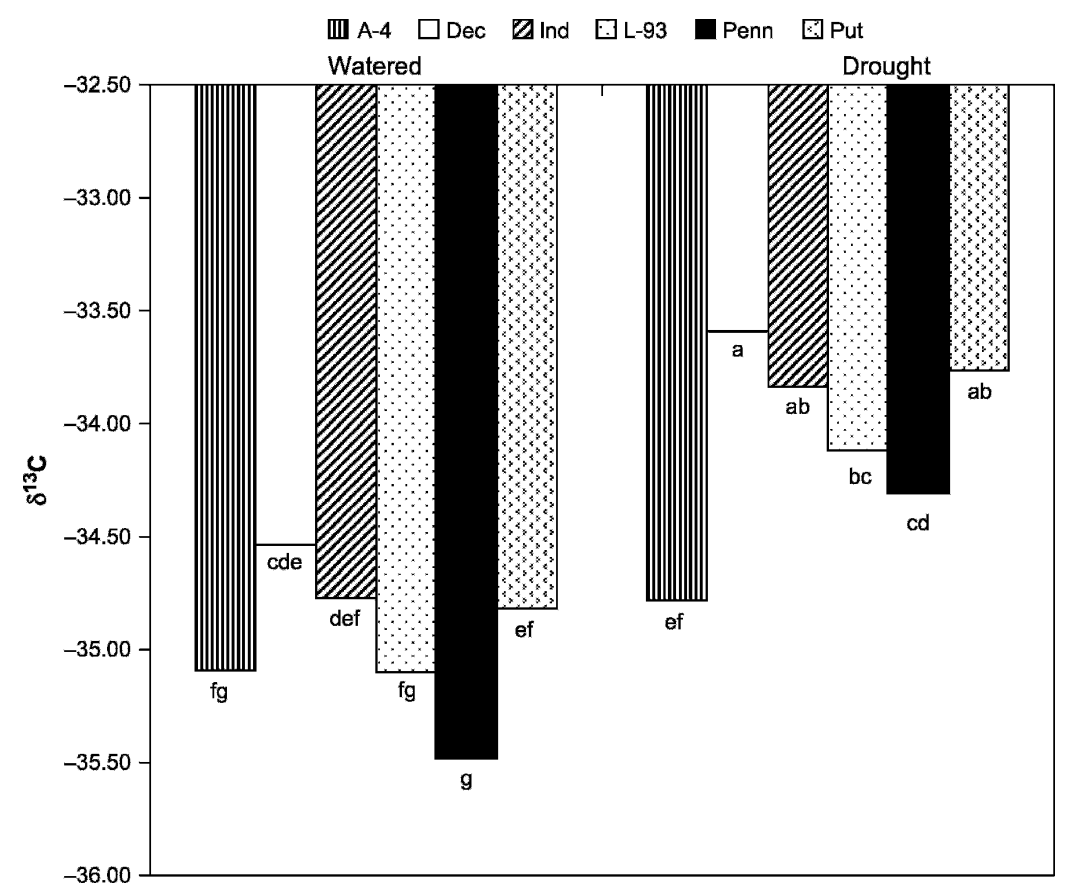

Fig. 6. Creeping bentgrass cultivar variation in carbon isotope discrimination $\left(\delta^{13} \mathrm{C}\right)$ under well-watered and drought stress at $14 \mathrm{~d}$ of treatment. Columns with the same lowercase letters are not significantly different based on least significant difference values $(P=0.05)$.

study, the two cultivars, 'Penn A-4' and 'L-93', that maintained higher RWC, turf quality, and leaf photochemical efficiency under drought stress had low OA. In contrast, 'Declaration' and 'Penncross', which did not perform well under drought stress, exhibited high levels of OA. These results suggest that OA was not a major mechanism for 'Penn A-4' and 'L-93' to tolerate drought stress, but was important for the survival of 'Declaration' and 'Penncross' under drought stress. The overall implication is that a particular species may use an important attribute such as OA, but that one mechanism alone will not necessarily predict comparative performance between cultivars.

The ability to maintain low ET rates has long been considered a trait for water 


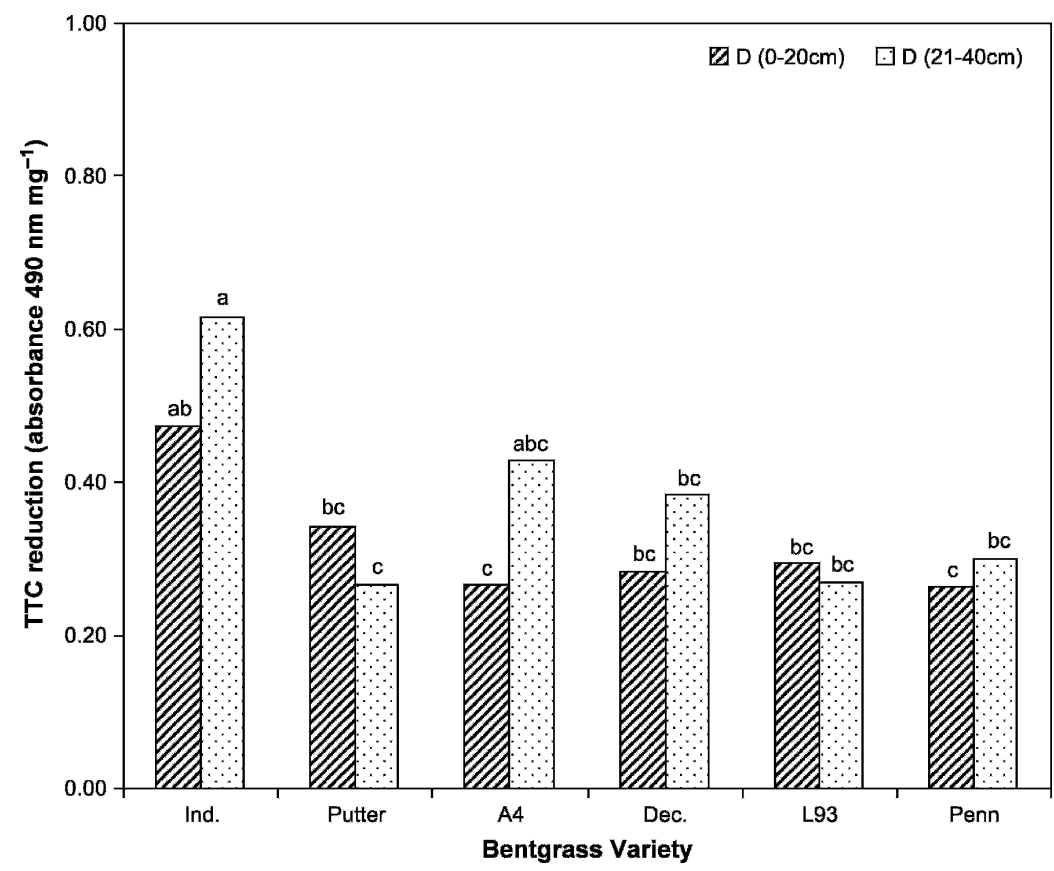

Fig. 7. Creeping bentgrass cultivar variation in root viability, expressed as TTC Reduction (absorbance $\left.490 \mathrm{~nm} \cdot \mathrm{mg}^{-1}\right)$, at $17 \mathrm{~d}$ of drought stress. Columns with the same lowercase letters are not significantly different based on least significant difference values $(P=0.05)$. TTC $=$ triphenyltetrazolium chloride.

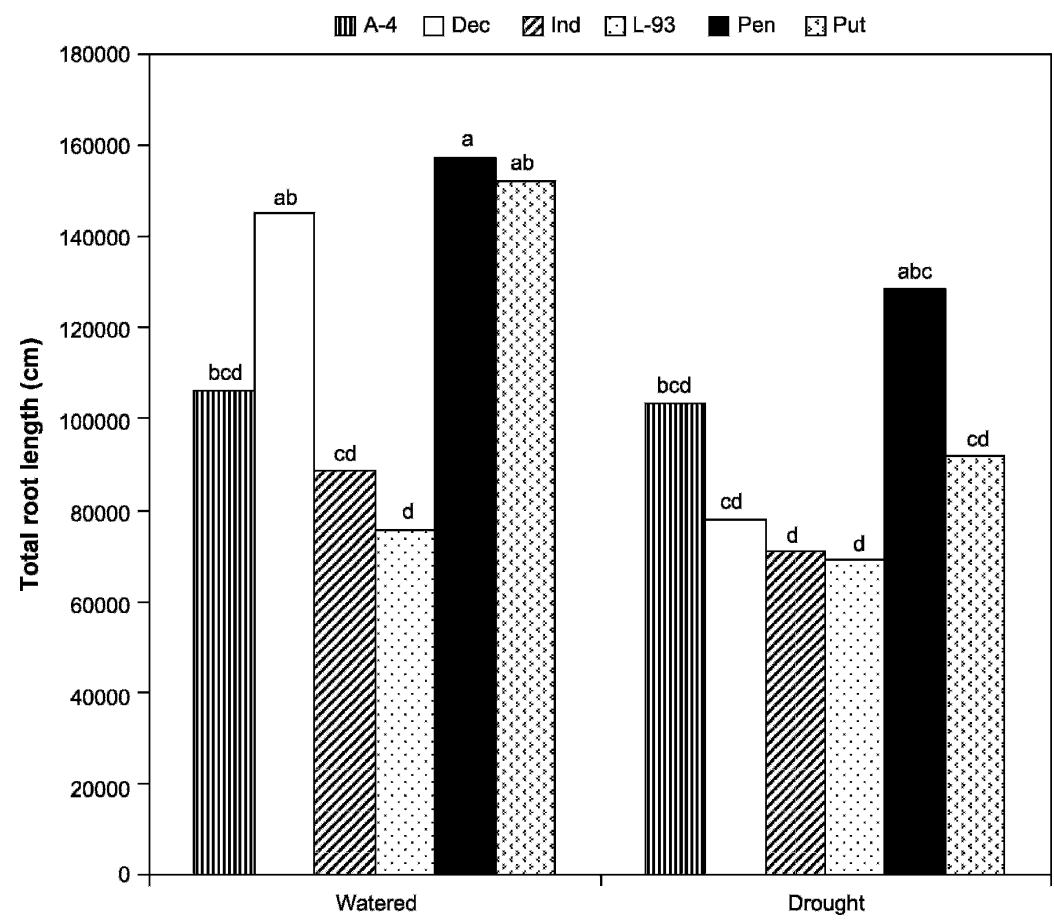

Fig. 8. Creeping bentgrass cultivar variation in total root length under well-watered (A) and drought stress (B) at $17 \mathrm{~d}$ of treatment. Columns with the same lowercase letters are not significantly different based on least significant difference values $(P=0.05)$.

conservation (Alves and Setter, 2000; Bacon et al., 1998; Kirkham, 1983). Salaiz et al. (1991) found significant variability in ET rates among different cultivars when comparing water use of different creeping bentgrass cultivars under well-watered field conditions. Our study also found cultivar variation in ET under well-watered conditions with 'L-93' being the lowest water user. These results indicated there was a potential for developing creeping bentgrass cultivars with reduced
(Lolium perenne L.) and reported that some tall fescue cultivars with higher water use maintained higher turf quality under drought stress than some perennial ryegrass cultivars with lower water use rates. Another study has shown better performance of drought stresstolerant Kentucky bluegrass cultivars with higher water use compared with poorer performing cultivars that adapted to drought by decreasing water use (Bonos and Murphy, 1999).

Carbon isotope discrimination $\left(\delta^{13} \mathrm{C}\right)$ has been associated with plant water use efficiency (WUE). Plants under water stress have been shown to discriminate less against $\mathrm{C}^{13}$ than $\mathrm{C}^{12}$ in the photosynthetic reaction (Farquhar et al., 1989; Lambers et al., 1998). As such, greater WUE is achieved when less carbon discrimination occurs or lower $\delta^{13} \mathrm{C}$ is correlated with higher WUE. Negative correlations between $\delta^{13} \mathrm{C}$ and WUE have been reported in Kentucky bluegrass (Ebdon and Kopp, 2004; Ebdon et al., 1998), tall fescue (Johnson, 1993; Johnson and Bassett, 1991), and perennial ryegrass (Johnson and Bassett, 1991). In the present study, cultivar variations in $\delta^{13} \mathrm{C}$ were observed under both wellwatered and drought stress conditions. Under well-watered conditions, 'Penncross' had the lowest $\delta^{13} \mathrm{C}$ and 'Declaration' had the highest $\delta^{13} \mathrm{C}$, suggesting that 'Penncross' had lower WUE than 'Declaration' under nonwaterlimiting conditions. Under drought stress, however, 'Penn A-4' had the highest $\delta^{13} \mathrm{C}$, suggesting that 'Penn A-4' may have maintained better growth and physiological functioning through other pathways such as cell membrane stability or by increasing antioxidant activity.

Rooting characteristics, including root viability, root length, and number, are important factors controlling water uptake of a root system. No cultivar variation in root viability was observed under well-watered conditions; however, 'Independence' maintained significantly higher root viability at the $20-$ to $40-\mathrm{cm}$ soil depth than other cultivars, suggesting that 'Independence' may be better able to maintain higher turf quality, $\mathrm{F}_{\mathrm{v}} / \mathrm{F}_{\mathrm{m}}$, and RWC under drought conditions by avoiding drought stress through maintaining more active roots for water uptake. These results also suggest the importance of maintaining higher root viability in deeper soil profiles where water may be more available than the surface soil.

The variation in drought avoidance between different turfgrass species has also been associated with the total amount of roots in deeper soil profiles under drought stress (Ervin and Koski, 1998). In our study, among the six cultivars compared, the three cultivars ('Penn A-4', 'Independence', and 'L-93') that showed the best turf quality performance had lower total root length than the other three cultivars under well-watered conditions. These same three cultivars showed only slight differences in total root length between well-watered and drought-stressed plants. However, 'Declaration', 'Penncross', and 'Putter' exhibited significant decline in total root length under drought conditions compared with their respective control. The data 


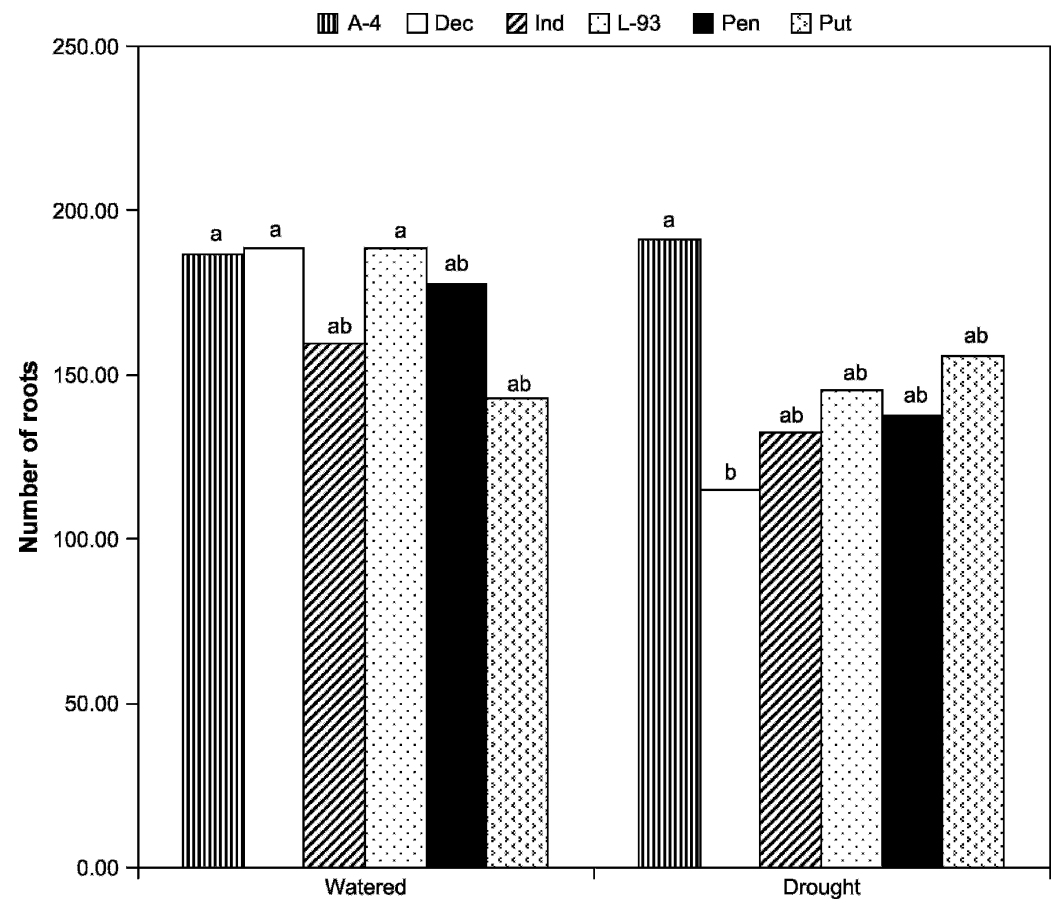

Fig. 9. Creeping bentgrass cultivar variation in total number of roots under well-watered (A) and drought stress (B) at $17 \mathrm{~d}$ of treatment. Columns with the same lowercase letters are not significantly different based on least significant difference values $(P=0.05)$.

suggest an extensive root system under wellwatered conditions does not necessarily correlate to greater drought resistance. In addition, 'Penn A-4', the cultivar with the highest turf quality under drought stress, showed no significant change in root number between well-watered and drought stress conditions, whereas other cultivars exhibited some extent of decline in root number under drought stress, particularly 'Declaration'. It seems that those cultivars with greater drought sensitivity are the first to lose roots when water becomes limited. In contrast, drought-resistant cultivars, particularly 'Penn A-4', had the ability to maintain root elongation and production even when drought was imposed. These results further suggested that 'Penn A-4' may sustain growth under drought through avoiding drought by developing persistent, extensive root systems.

In summary, our results demonstrated genetic variation in drought tolerance and drought avoidance characteristics in creeping bentgrass cultivars. The three newer cultivars, 'Penn A-4', 'Independence', and 'L-93', performed better than other three cultivars under drought conditions. The majority of physiological parameters evaluated suggested that creeping bentgrass cultivars that were better able to survive drought stress were mainly through some avoidance mechanisms such as maintaining higher WUE, root viability, root elongation, and production under drought stress. These parameters could be used as criteria to select for drought resistant bentgrass cultivars.

\section{Literature Cited}

Alves, A.A.C. and T.L. Setter. 2000. Response of cassava to water deficit: Leaf area growth and abscisic acid. Crop Sci. 40:131-137.
Bacon, M.A., S. Wilkinson, and W.J. Davies. 1998. $\mathrm{pH}-$ regulated leaf cell expansion in droughted plants is abscisic acid dependent. Plant Physiol. 118:1507-1515.

Blum, A. 1989. Osmotic adjustment and growth of barley genotypes under drought stress. Crop Sci. 29:230-233.

Blum, A. and C.Y. Sullivan. 1986. The comparative drought resistance of landraces of sorghum and millet from dry and humid regions. Ann. Bot. (Lond.) 57:835-846.

Bohnert, H.J., D.E. Nelson, and R.G. Jensen. 1995. Adaptations to environmental stresses. Plant Cell 7:1099-1111.

Bonos, S.A. and J.A. Murphy. 1999. Growth responses and performance of Kentucky bluegrass under summer stress. Crop Sci. 39:770774.

Bonos, S.A., D. Rush, K. Hignight, and W.A Meyer. 2004. Selection for deep root production in tall fescue and perennial ryegrass. Crop Sci. 44:1710-1775.

Carrow, R.N. 1996. Drought resistance aspects of turfgrasses in the southeast: Root-shoot responses. Crop Sci. 36:687-694.

DaCosta, M. and B. Huang. 2006. Osmotic adjustment associated with variation in bentgrass tolerance to drought stress. J. Amer. Soc. Hort. Sci. 131:338-344.

Ebdon, J.S. and K.L. Kopp. 2004. Relationships between water use efficiency, carbon isotope discrimination, and turf performance in genotypes of Kentucky bluegrass during drought. Crop Sci. 44:1754-1762.

Ebdon, J.S., A.M. Petrovic, and T.E. Dawson. 1998. Relationship between carbon isotope discrimination, water use efficiency, and evapotranspiration in Kentucky bluegrass. Crop Sci. 38:157-162.

Engelke, M.C., V.G. Lehman, C. Mays, P.F. Colbaugh, J.A. Reinert, and W.E. Knoop. 1995. Registration of 'Cato' creeping bentgrass. Crop Sci. 35:590-591.

Ervin, E.H. and A.J. Koski. 1998. Drought avoidance aspects and crop coefficients of Kentucky bluegrass and tall fescue turfs in the semiarid West. Crop Sci. 38:788-795.

Farquhar, G.D., J.R. Ehleringer, and K.T. Hubick. 1989. Carbon isotope discrimination and photosynthesis. Ann. Rev. Plant Physiol. Plant Mol. Bio. 40:503-537.

Fernandez, G.C.J. and B. Love. 1993. Comparing turfgrass cumulative evapotranspiration curves. HortScience 28:732-734.

Huang, B. 1999. Water relations and root activities of Buchloe dactyloides and Zoysia japonica in response to localized soil drying. Plant Soil 208:179-186.

Huang, B., R.R. Duncan, and R.N. Carrow. 1997. Drought-resistance mechanisms of seven warmseason turfgrasses under surface soil drying: II. Root aspects. Crop Sci. 37:1863-1869.

Huang, B. and Y. Jiang. 2002. Physiological and biochemical responses of plants to drought and heat stress, p. 287-301. In: Kang, M. (ed.). Crop improvement: challenges in the twentyfirst century. Food Products Press, New York.

Johnson, R.C. 1993. Carbon isotope discrimination, water relations, and photosynthesis in tall fescue. Crop Sci. 33:169-174.

Johnson, R.C. and L.M. Bassett. 1991. Carbon isotope discrimination and water use efficiency in four cool-season grasses. Crop Sci. 31:157-162.

Kirkham, M.B. 1983. Effect of ABA on the water relations of winter-wheat cultivars varying in drought resistance. Physiol. Plant. 59:153-157.

Knievel, D.P. 1973. Procedure for estimating ratio of living to dead root dry matter in root core sample. Crop Sci. 13:124-126.

Lambers, H., F.S. Chapin, and T.L. Pons. 1998. Plant physiological ecology. Springer-Verlag New York Inc., New York.

LaRosa, C.P., P.M. Hasegawa, D. Rhodes, J.M. Clithero, A.A. Watad, and R.A. Bressan. 1987. Abscisic acid stimulated osmotic adjustment and its involvement in adaptation to tobacco cells to NaCl. Plant Physiol. 85:174-181.

McCann, S.E. and B. Huang. 2007. Effects of trinexapac-foliar application on creeping bentgrass responses to combined drought and heat stress. Crop. Sci. 47:2121-2128.

McMichael, B.L. and J.J. Burke. 1994. Metabolic activity of cotton roots in response to temperature. Environ. Exp. Bot. 34:201-206.

Nilsen, E.T. and D.M. Orcutt. 1996. Physiology of plants under stress-Abiotic factors. John Wiley \& Sons, New York.

Perdomo, P., J.A. Murphy, and G.A. Berkowitz. 1996. Physiological changes associated with performance of Kentucky bluegrass cultivars during summer stress. HortScience 31:1182-1186.

Qian, Y. and J.D. Fry. 1997. Water relations and drought tolerance of four turfgrasses. J. Amer. Soc. Hort. Sci. 122:129-133.

Salaiz, T.A., R.C. Sherman, T.P. Riordan, and E.J. Kinbacher. 1991. Creeping bentgrass cultivar water use and rooting responses. Crop Sci. 31:1331-1334.

Sheffer, K.M., J.H. Dunn, and D.D. Minner. 1987. Summer drought response and rooting depth of three cool-season turfgrasses. HortScience 22:296-297.

Smedley, M.P., T.E. Dawson, J.P. Comstock, L.A. Donovan, D.E. Sherrill, C.S. Cook, and J.R. Ehleringer. 1991. Seasonal carbon isotope discrimination in a grassland community. Oecologia 85:314-320.

Turgeon, A.J. 1999. Turfgrass management. 5th ed. Prentice Hall, Upper Saddle, NJ. p. 4, 225.

White, R.H., M.C. Engelke, S.J. Morton, J.M. Johnson-Cicalese, and B.A. Ruemmele. 1992. Acremonium endophyte effects on tall fescue drought tolerance. Crop Sci. 32:1392-1396. 